\title{
PENGARUH PELATIHAN KERJA TERHADAP KINERJA KARYAWAN PADA PT BANK SYARIAH MANDIRI CABANG MADIUN TAHUN 2014
}

\author{
Riana Meiprahastuti \\ Mahasiswa Prodi Pendidikan Ekonomi IKIP PGRI Madiun
}

\begin{abstract}
Abstrak: Tujuan dari penelitian ini adalah untuk menentukan pelatihan kerja yang diikuti oleh karyawan "PT Bank Syariah Mandiri Cabang Madiun", untuk mengetahui kinerja karyawan "PT Bank Syariah Mandiri Cabang Madiun", serta untuk menentukan apakah ada pengaruh pelatihan kerja terhadap kinerja karyawan pada "PT Bank Syariah Mandiri Cabang Madiun". sampel dalam penelitian ini menggunakan sampel jenuh, semua karyawan "PT Bank Syariah Mandiri Cabang Madiun", sebesar 23 orang-orang. pengumpulan data menggunakan kuesioner dan dokumentasi. Dalam menganalisis data digunakan metode statistik korelasi produk moment untuk menguji apakah ada pengaruh atau tidak, alat dan metode yang digunakan untuk uji regresi valid yaitu dengan hipotesis yang diajukan dalam hasil pembelajaran. Hasil penelitian menunjukkan bahwa ada pengaruh posistif antara pemberian pelatihan kerja terhadap kinerja karyawanpada " PT Bank Syariah Mandiri Cabang Madiun ". Hal ini diperoleh dari uji korelasi, menunjukkan $r_{\text {hitung }}$ adalah $r_{\text {tabel }}$ 0,4130 sedangkan besarnya $\operatorname{Sig}_{\text {hit }} \operatorname{Sig}_{\text {prob }} 0,05$. Ini berarti bahwa nilai $r_{\text {hitung }} \geq r_{\text {tabel }}(0,809 \geq 0,413)$ atau $\operatorname{Sig}_{\text {hit }} \leq \operatorname{Sig}_{\text {prob }}(0,000 \leq 0,05)$ berarti penolakan H0 yang menunjukkan bahwa pelatihan kerja memiliki hubungan dengan kinerja karyawan pada "PT Bank Syariah Mandiri Cabang Madiun". Hasil tes juga diperoleh Fisher, $\mathrm{F}_{\text {hitung }}$ adalah 39,678 sedangkan nilai $\mathrm{F}_{\text {tabel }}$ 4,325 di sisi lain adalah 0,000 sedangkan besarnya Sighit Sigprob0.05. Ini berarti bahwa nilai $\mathrm{F}_{\text {hitung }} \geq$ $F_{\text {tabel }}(39,678 \geq 4,325)$ atau $\operatorname{Sig}_{\text {hit }} \leq \operatorname{Sig}_{\text {prob }}(0,000 \leq 0,05)$ berarti $\mathrm{H} 0$ ditolak yang menunjukkan bahwa ada pelatihan kerja yang signifikan terhadap kinerja karyawan di "PT Bank Syariah Mandiri Cabang Madiun". Hasil uji $t, t_{\text {hitung }}$ adalah 6,299 sedangkan $t_{\text {tabel }}$ dari 1,721, di sisi lain nilai Sighit adalah 0,000 sedangkan Sigprob 0,05. Ini berarti bahwa nilai $t_{\text {hitung }} \geq t_{\text {tabel }}$ $(6,299 \geq 1,721)$ atau atau $\operatorname{Sig}_{\text {hit }} \leq \operatorname{Sig}_{\text {prob }}(0,000 \leq 0,05)$ berarti penolakan H0 yang menunjukkan bahwa ada efek yang berbeda dari pelatihan kerja terhadap kinerja karyawan di "PT Bank Syariah Mandiri Cabang Madiun". Hasil R2 yaitu 0,654 menunjukkan bahwa $65,4 \%$ dari karyawan dipengaruhi oleh kinerja dari pelatihan, sedangkan sisanya $34,6 \%$
\end{abstract}

Kata kunci:Pelatihan Kerja, Kinerja Karyawan.

\section{Pendahuluan}

Manajemen perbankan tidak mungkin lepas dari faktor kualitas SDM karena merupakan faktor yang sangat penting. Berbagai usaha dilakukan untuk peningkatan kinerja karyawan yang profesional bahkan penyediaan dana untuk pengembangan atau pelatihan bagi karyawan.

Menurut Undang-undang Negara Republik Indonesia Nomor 10 Tahun 1998 Tanggal 10 November 1998 tentang perbankan, yang dimaksud dengan "Bank adalah 
badan usaha yang menghimpun dana dari masyarakat dalam bentuk simpanan dan menyalurkannya kepada masyarakat dalam bentuk kredit dan atau bentuk-bentuk lainnya dalam rangka meningkatkan taraf hidup rakyat banyak".

Dengan adanya jasa perbankan tersebut, masyarakat menemukan kemudahan dalam melakukan kegiatan transaksi untuk menjalankan kegiatan ekonominya. Untuk itu karyawan bank perlu mengetahui apa saja yang menjadi produk jasa dari perbankan agar masyarakat bisa memanfaatkan jasa tersebut sesuai dengan kebutuhan mereka.

Kemampuan karyawan dalam memberikan pelayanan kepada nasabah memiliki peran penting karena tidak mungkin kegiatan operasional bank dapat berjalan lancar tanpa adanya campur tangan karyawan. Karyawan di bank harus memiliki kinerja yang baik agar bisa melayani kebutuhan konsumen dengan baik.

Menurut Hersey and Blanchard (dalam Sjafri Mangkuprawira 2009:219).

Kinerja merupakan suatu fungsi dari motivasi dan kemampuan. Untuk menyelesaikan tugas atau pekerjaan, seseorang harus memiliki derajat kesediaan dan tingkat kemampuan tertentu. Kesediaan dan ketrampilan seseorang tidaklah cukup efektif untuk mengerjakan sesuatu tanpa pemahaman yang jelas tentang apa yang akan dikerjakan dan bagaimana mengerjakannya.

Jadi sebelum karyawan melaksanakan tugasnya mereka harus faham mengenai ketentuan, sistem dan cara kerja mereka terlebih dahulu sehingga nantinya dapat mempermudah mereka dalam melaksanakan pekerjaannya.

Salah satu cara untuk meningkatkan kinerja karyawan adalah dengan mengadakan program pelatihan kerja. Pelatihan kerja sangatlah dibutuhkan agar karyawan mampu beradaptasi terhadap berbagai perubahan yang akan dihadapi oleh perusahaan. Tinggi rendahnya kinerja karyawan berkaitan erat dengan pelatihan yang diterapkan oleh perusahaan tempat mereka bekerja.

Menurut Sunarto dkk (2003:67) "pelatihan adalah proses sistematik pengubahan perilaku karyawan dalam suatu arah guna meningkatkan tujuan organisasional".

Persoalan yang sering timbul dalam pelatihan yang dilakukan perusahaan seringkali belum sesuai dengan kebutuhan organisasi. Program pelatihan yang diterapkan dalam dunia perbankan umumnya diterapkan pada karyawan baru yang belum mempunyai pengetahuan secara menyeluruh.

Pemberian program pelatihan bertujuan untuk meningkatkan kinerja, memberikan pemahaman karyawan tentang bagaimana memberikan pelayanan dan informasi yang baik bagi konsumen, sehingga nantinya mampu membantu kelancaran aktivitas yang ada di perusahaan tanpa ada suatu kendala yang terlalu sulit.

Terjadi perbedaan antara karyawan yang pernah mengikuti pelatihan dengan karyawan yang belum pernah mengikuti pelatihan. Karyawan yang pernah mendapatkan pelatihan tentu memiliki pengetahuan, kecakapan, ketrampilan, dan kinerja yang lebih baik daripada karyawan yang belum atau tidak pernah mengikuti pelatihan sama sekali.

Kinerja di dalam suatu organisasi dilakukan oleh seluruh sumber daya manusia yang ada dalam organisasi tersebut. Setiap individu yang ada di dalamnya mempunyai kemampuan yang berbeda, hal tersebut tidak hanya dipengaruhi oleh peralatan atau teknologi yang digunakan saat bekeja, tetapi faktor pengetahuan dan ketrampilan, kompetensi yang dimiliki, kepribadian dan sikap juga dapat mempengaruhi kinerja mereka.

Menurut Veithzal Rivai Ahmad Fawzi (dalam Sjafri Mangkuprawira 2009:218) "kinerja dalah hasil atau tingkat keberhasilan seseorang secara keseluruhan selama periode tertentu di dalam melaksanakan tugas dibandingkan dengan berbagai kemungkinan, seperti standar hasil kerja, target atau sasaran 
atau kriteria yang telah ditentukan terlebih dahulu dan telah disepakati bersama".

Sedangkan A. A. Anwar Prabu Mangkunegara (2005: 9) menyatakan bahwa "kinerja karyawan (prestasi kerja) adalah hasil kerja secara kualitas dan kuantitas yang dicapai oleh seseorang karyawan dalam melaksanakan tugasnya sesuai dengan tanggung jawab yang diberikan kepadanya".

Sjafri Mangkuprawira (2002:135) "Pelatihan bagi karyawan merupakan sebuah proses mengajarkan pengetahuan dan keahlian tertentu serta sikap agar karyawan semakin terampil dan mampu melaksanakan tanggung jawabnya dengan semakin baik, sesuai dengan standar". Menurut Gary Dessler (dalam Suwatno dan Donni Juni Priansa 2011:118) "pelatihan adalah merupakan proses mengajarkan karyawan baru atau yang ada sekarang, ketrampilan dasar yang mereka butuhkan untuk menjalankan pekerjaan mereka". Sedangkan Menurut Ruky (dalam Edy Sutrisno 2009:67) "pelatihan didefinisikan sebagai usaha untuk meningkatkan kinerja karyawan dalam pekerjaannya sekarang atau dalam pekerjaan lain yang akan dijabatnya segera".

Jadi pelatihan dapat disimpulkan bahwa pelatihan merupakan sebuah proses untuk meningkatkan kompetensi karyawan. Pelatihan juga bukan merupakan suatu pemborosan mengingat hasil atau manfaatnya jauh lebih besar dari pada biaya atau waktu yang harus disediakan. Pelatihan merupakan cara yang baik untuk meningkatkan kinerja.

Pelatihan kerja mempunyai pengaruh terhadap kinerja karyawan. Hal ini terlihat dari tujuan pelatihan salah satunya adalah untuk memperbaiki kinerja. Sedangkan Sjafri Mangkuprawira (2002: 135) menyatakan "Pelatihan .... dari program di dalam dan luar pekerjaan karyawan yang dimanfaatkan perusahaan dalam mengembangkan ketrampilan dan pengetahuan, utamanya untuk kinerja pekerjaan dan promosi karir".

Dengan diadakannya program pelatihan kerja bagi karyawan dapat meningkat kan pengetahuan dan pengalaman kerja di dalam perusahaan yang bersangkutan. Selain itu pelatihan kerja yang baik dalam perusahaan akan mendorong karyawan untuk bekerja dengan maksimal dengan penuh tanggung jawab dalam melaksanakan tugastugas yang diberikan kepadanya. Pelatihan merupakan kunci manajemen tenaga kerja yang tidak dapat dipisahkan. Secara tidak langsung pelatihan memiliki pengaruh terhadap meningkatnya kinerja karyawan.

\section{Metodologi Penelitian}

Tempat penelitian dilaksanakan di "PT Bank Syariah Mandiri Cabang Madiun" dengan alamat Jalan Cokroaminoto, No.41 Madiun. Rancangan penelitian yang digunakan dalam penelitian ini adalah penelitian kausal-komparatif.

Variabel yang digunakan dalam penelitian ini terdiri dari dua variabel yaitu variabel Bebas (variabel independent). adalah pelatihan kerja. Variabel Terikat (Y) adalah kinerja karyawan.

Adapun yang menjadi sampel dalam penelitian ini yaitu seluruh karyawan PT Bank Syariah Mandiri Cabang Madiun yang berjumlah 23 karyawan. Teknik pengambilan sampel dalam penelitian ini menggunakan teknik sampel jenuh. Gabriel Amin Silalahi (2003:76) menyatakan bahwa "sampel jenuh adalah teknik penentuan sampel bila semua anggota populasi digunakan sebagai sampel". Hal ini berarti sampel yang digunakan sebagai objek penelitian adalah sebanyak 23 karyawan "PT Bank Syariah Mandiri Cabang Madiun".

Dalam penelitian ini teknik pengumpulan data yang digunakan adalah kuesioner. Kuesioneryang digunakan dalam penelitian ini merupakan kuesioner tertutup dimana responden tinggal memilih jawaban yang telah disediakan dalam kuesioner tersebut. Jumlah soal yang adaa dalam kuesioner ini adalah 40 butir soal yang terbagi dalam 2 variabel yang akan diteliti. 20 soal untuk variabel pelatihan kerja (X) dan 20 soal untuk 
variabel kinerja karyawan (Y). Selanjutnya tentang jumlah dan indikator soal dapat dilihat pada instrumen penelitian.

\section{Hasil Penelitian}

Deskripsi variabel pelatihan kerja dengan jumlah data $(\mathrm{N})$ sebanyak 23 mempunyai deskripsi data sebagai berikut: (a) jumlah skor total sebesar 1935; (b) nilai rata-rata hitung (mean) sebesar 84,13; (c) median sebesar 82,00; (d) modus sebesar 80; (e) standar deviasi sebesar 7,570; (f) nilai minimum sebesar 72; (g) nilai maximum sebesar 100. Dari hasil analisis deskriptif dapat dikatakan pelatihan kerja di "PT Bank Syariah Mandiri Cabang Madiun" Tahun 2012 cukup baik, Karena yang berada di atas nilai rata-rata $\geq 84,13$ sebanyak 10 karyawan. Sedangkan yang berada di bawah nilai ratarata sebanyak 13 karyawan.

Deskripsi variabel kinerja karyawan dengan jumlah data (N) sebanyak 23 mempunyai deskripsi data sebagai berikut: (a) jumlah skor total sebesar 1978; (b) nilai rata-rata hitung (mean) sebesar 86.00; (c) median sebesar 85.00; (d) modus sebesar 85; (e) standar deviasi sebesar 6.928; (f) nilai minimum sebesar 77; (g) nilai maximum sebesar 100. Dari hasil analisis deskriptif dapat dikatakan kinerja karyawan di "PT Bank Syariah Mandiri Cabang Madiun" Tahun 2012 adalah rendah, Karena yang berada diatas nilai rata-rata $\geq 86.00$ sebanyak 9 karyawan. Sedangkan yang berada di bawah nilai rata-rata sebanyak 14 karyawan. Rendahnya kinerja tersebut dapat dipengaruhi oleh situasi kerja antara lain hubungan kerja antar sesama karyawan yang rendah, serta pengaruh kebijakan pemimpin, dan pola kepemimpinan kerja.

\section{Pengujian Hipotesis}

Diperoleh nilai $r_{\text {hitung }}$ adalah 0,809 sedangkan $r_{\text {tabel }}$ 0,413. Selain itu nilai $\mathrm{Sig}_{\text {hit }}$ adalah 0,000 sedangkan $\operatorname{Sig}_{\text {prob }} 0,05$. Hal iniberartibahwanilair $_{\text {hitung }} \geq r_{\text {tabel }}(0,809 \geq 0,413)$ atau $\operatorname{Sig}_{\text {hit }} \leq \operatorname{Sig}_{\text {prob }}(0,000 \leq 0,05)$. Atas dasar uji korelasi tersebut dapat disimpulkan tolak $\mathrm{H}_{0}$, artinya ada hubungan pelatihan kerja dengan kinerja karyawan pada "PT Bank Syariah Mandiri Cabang Madiun” Tahun 2012.

Di lain pihak dalam uji determinasi yang diperoleh nilai $\mathrm{R}^{2}$ ( $\mathrm{R}$ Square) atau koefisien determinasi yang digunakan untuk mengetahui seberapa besar prosentase sumbangan pelatihan kerja terhadap kinerja karyawan. Berdasarkan tabel 4.10. tersebut di atas dapat diketahui nilai $\mathrm{R}^{2}$ adalah 0,654 . Jadi sumbangan pengaruh dari pelatihan kerja terhadap kinerja karyawan yaitu $65,4 \%$ sedangkan sisanya sebesar $34,6 \%$ dipengaruhi oleh faktor lain.

Dari penghitungan diperoleh nilai $\mathrm{F}_{\text {hitung }}$ adalah 39,678 sedangkan $F_{\text {tabel }}$ sebesar 4,325, dilain pihak besarnya $\mathrm{Sig}_{\text {hit }}$ adalah 0,000 sedangkan $\operatorname{Sig}_{\text {prob }}$ 0,05. Hal ini berarti bahwa nilai $F_{\text {hitung }} \geq F_{\text {tabel }}(39,678 \geq 4,325)$ atau $\operatorname{Sig}_{\text {hit }}$ $\leq \operatorname{Sig}_{\text {prob }}(0,000 \leq 0,05)$. Atas dasar uji Fisher tersebut dapat disimpulkan tolak $\mathrm{H}_{0}$, artinya ada pengaruh pelatihan kerja terhadap kinerja karyawan pada "PT Bank Syariah Mandiri Cabang Madiun" Tahun 2012.

Selain digunakan untuk mencari pengaruh, uji Fisher atau Anova bisa juga digunakan untuk menguji linearitas. Karena $\mathrm{F}_{\text {hitung }}$ sebesar 39,678 $\geq \mathrm{F}_{\text {tabel }}$ sebesar 4,325, berarti ada hubungan yang linier antara variabel pelatihan kerja dengan kinerja karyawan.Atas dasar tabel Hasil Uji tdapat dibuat persamaan garis regresi sebagai berikut: $\mathrm{Y}=23,733+0,740 \mathrm{X}$, artinya adalah apabila pelatihan kerja ditingkatkan satu kali akan terjadi kenaikan kinerja karyawan sebanyak $0,740 \%$, apabila faktor yang lainnya tetap.

Selanjutnya dari tabel di atas dapat diketahui bahwa nilai $t_{\text {hitung }}$ adalah 6,299 sedangkan $t_{\text {tabel }}$ sebesar 1,721, dilain pihak nilai $\operatorname{Sig}_{\text {hit }}$ adalah 0,000 sedangkan $\operatorname{Sig}_{\text {prob }} 0,05$. Hal ini berarti bahwa nilai $t_{\text {hitung }} \geq t_{\text {tabel }}(6,299 \geq$ $1,721)$ atau $\operatorname{Sig}_{\text {hit }} \leq \operatorname{Sig}_{\text {prob }}(0,000 \leq 0,05)$. Atas 
dasar uji t tersebut dapat disimpulkan tolak $\mathrm{H}_{0}$, artinya ada beda pengaruh pelatihan kerja terhadap kinerja karyawan pada "PT Bank Syariah Mandiri Cabang Madiun" Tahun 2012.

\section{Simpulan Hasil Analisis}

Simpulan Uji Korelasi

Hasil dari pengujian korelasi dapat diperoleh besarnya nilai $\mathrm{r}_{\text {hitung }}$ adalah 0,809 sedangkan $r_{\text {tabel }} 0,413$, dilain pihak besarnya Sig $_{\text {hit }}$ adalah 0,000 sedangkan $\operatorname{Sig}_{\text {prob }} 0,05$. Hal ini berarti bahwa nilai $r_{\text {hitung }} \geq r_{\text {tabel }}(0,809 \geq$ $0,413)$ atau $\operatorname{Sig}_{\text {hit }} \leq \operatorname{Sig}_{\text {prob }}(0,000 \leq 0,05)$. Selain itu diperoleh nilai $\mathrm{R}^{2}$ adalah 0,654 . Jadi sumbangan pengaruh dari pelatihan kerja terhadap kinerja karyawan yaitu $65,4 \%$.

Sesuai hipotesis yang diajukan dapat diperoleh simpulan bahwa ada hubungan pelatihan kerja dengan kinerja karyawan pada "PT Bank Syariah Mandiri Cabang Madiun" Tahun 2012. Berarti $\mathrm{H}_{0}$ ditolak.

\section{Simpulan Uji Fisher}

Hasil dari pengujian Fisher dengan uji Anova dapat diperoleh nilai $F_{\text {hitung }}$ adalah 39,678 sedangkan $\mathrm{F}_{\text {tabel }}$ sebesar 4,325 , di lain pihak besarnya $\operatorname{Sig}_{\text {hit }}$ adalah 0,000 sedangkan $\operatorname{Sig}_{\text {prob }}$ 0,05. Hal ini berarti bahwa nilai $F_{\text {hitung }} \geq F_{\text {tabel }}(39,678 \geq 4,325)$ atau $\operatorname{Sig}_{\text {hit }} \leq$ $\operatorname{Sig}_{\text {prob }}(0,000 \leq 0,05)$. Sesuai hipotesis yang diajukan dapat diperoleh simpulan bahwa ada pengaruh pelatihan kerja terhadap kinerja karyawan pada "PT Bank Syariah Mandiri Cabang Madiun" Tahun 2012. Berarti $\mathrm{H}_{0}$ ditolak.

\section{Simpulan Uji t}

Dari hasil perhitungan atau pengujian yang dilakukan diperoleh persamaan regresi sebagai berikut: $\mathrm{Y}=23,733+0,740 \mathrm{X}$, simpulannya adalah apabila pelatihan kerja ditingkatkan satu kali akan terjadi kenaikan kinerja karyawan sebanyak $0,740 \%$, apabila faktor yang lainnya tetap.
Hasil dari uji t dapat diperoleh nilai $t_{\text {hitung }}$ adalah 6,299 sedangkan $t_{\text {tabel }}$ sebesar 1,721, dilain pihak nilai $\operatorname{Sig}_{\text {hit }}$ adalah 0,000 sedangkan $\mathrm{Sig}_{\text {prob }}$ 0,05. Hal ini berarti bahwa nilai $\mathrm{t}_{\text {hitung }} \geq \mathrm{t}_{\text {tabel }}(6,299 \geq 1,721)$ atau $\operatorname{Sig}_{\text {hit }} \leq$ $\operatorname{Sig}_{\text {prob }}(0,000 \leq 0,05)$. Sesuai hipotesis yang diajukan dapat diperoleh simpulan bahwa ada beda pengaruh pelatihan kerja terhadap kinerja karyawan pada "PT Bank Syariah Mandiri Cabang Madiun" Tahun 2012. Berarti $\mathrm{H}_{0}$ ditolak.

\section{Pembahasan}

Hasil penelitian menunjukkan bahwa pelatihan kerja mempunyai hubungan sekaligus pengaruh terhadap kinerja karyawan. Artinya pelatihan kerja yang diberikan kepada karyawan adalah salah satu cara guna memecahkan masalah yang dihadapi oleh karyawan dalam pekerjaannya. Serangkaian pelatihan dalam berbagai bidang yang diberikan oleh perusahaan membantu karyawan dalam memecahkan masalah organisasional dan melaksanakan pekerjaan secara efektif. Dengan adanya pelatihan maka secara tidak langsung kinerja karyawan semakin meningkat.

Hal tersebut sesuai dengan pendapat yang dikemukakan oleh Sjafri Mangkuprawira (2002: 135) "Pelatihan.... dari program di dalam dan luar pekerjaan karyawan yang dimanfaatkan perusahaan dalam mengembangkan ketrampilan dan pengetahuan, utamanya untuk kinerja pekerjaan dan promosi karir".

Selain itu juga sesuai dengan tujuan pelatihan menurut Sunarto (2003:68) salah satunya adalah memperbaiki kinerja. Dengan adanya pelatihan, maka karyawan dapat memperbaiki prestasi kerja pada suatu pekerjaan tertentu menunjukkan bahwa pelatihan kerja diperlukan oleh karyawan untuk membantu melaksanakan pekerjaan yang menjadi tugas dan tanggung jawabnya secara lebih baik agar terjadi peningkatan kinerja karyawan. 
Selanjutnya adalah pembahasan untuk uji regresi (uji korelasi, uji Fisher, dan uji t):

1. Pembahasan Uji Korelasi

Untuk uji korelasi diperoleh nilai $r_{\text {hitung }}$ adalah 0,809 sedangkan $r_{\text {tabel }} 0,413$, dilain pihak besarnya $\mathrm{Sig}_{\text {hit }}$ adalah 0,000 sedangkan $\operatorname{Sig}_{\text {prob }} 0,05$. Hal ini berarti bahwa nilai $r_{\text {hitung }} \geq r_{\text {tabel }}(0,809 \geq 0,413)$ atau $\operatorname{Sig}_{\text {hit }} \leq \operatorname{Sig}_{\text {prob }}(0,000 \leq 0,05)$. Dengan demikian $\mathrm{H}_{0}$ ditolak, artinya ada hubungan pelatihan kerja dengan kinerja karyawan pada "PT Bank Syariah Mandiri Cabang Madiun" tahun 2012.

Nilai $\mathrm{R}^{2}$ yang diperoleh adalah sebesar 54,8\%. Menunjukkan bahwa pelatihan kerja mempengaruhi kinerja karyawan sebanyak $54,8 \%$.

\section{Pembahasan Uji Fisher}

Untuk uji Fisher diperoleh nilai $F_{\text {hitung }}$ adalah 39,678 sedangkan $F_{\text {tabel }}$ sebesar 4,325 dilain pihak besarnya Sig $_{\text {hit }}$ adalah 0,000 sedangkan $\mathrm{Sig}_{\text {prob }}$ 0,05. Hal ini berarti bahwa nilai $F_{\text {hitung }} \geq F_{\text {tabel }}(39,678$ $\geq 4,325)$ atau $\operatorname{Sig}_{\text {hit }} \leq \operatorname{Sig}_{\text {prob }}(0,000 \leq 0,05)$. Dengan demikian $\mathrm{H}_{0}$ ditolak, artinya ada pengaruh pelatihan kerja terhadap kinerja karyawan pada "PT Bank Syariah Mandiri Cabang Madiun" tahun 2012.

3. Pembahasan Ujit

Dapat dilihat pada hasil persamaan regresi $\mathrm{Y}=23,733+0,740 \mathrm{X}$ Artinya apabila pelatihan kerja ditingkatkan satu kali akan terjadi kenaikan kinerja karyawan sebanyak $0,740 \%$, apabila faktor yang lainnya tetap.

Untuk uji $t$ diperoleh nilai $t_{\text {hitung }}$ adalah 6,299 sedangkan $\mathrm{t}_{\text {tabel }}$ sebesar 1,721, dilain pihak nilai $\mathrm{Sig}_{\text {hit }}$ adalah 0,000 sedangkan $\operatorname{Sig}_{\text {prob }} 0,05$. Hal ini berarti bahwa nilai $t_{\text {hitung }} \geq t_{\text {tabel }}(6,299 \geq 1,721)$ atau $\operatorname{Sig}_{\text {hit }} \leq \operatorname{Sig}_{\text {prob }}(0,000 \leq 0,05)$. Dengan demikian $\mathrm{H}_{0}$ ditolak, artinya ada beda pengaruh pelatihan kerja terhadap kinerja karyawan pada "PT Bank Syariah Mandiri Cabang Madiun" Tahun 2012.

\section{Penutup \\ Simpulan}

Berdasarkan hasil analisis data dan pembahasan, dapat disimpulkan sebagai berikut:

Pelatihan kerja yang dilaksanakan oleh PT Bank Syariah Mandiri Cabang Madiun, dikatakan cukup baik. Hal ini dapat dilihat dari hasil statistik deskriptif dengan jumlah (N) sebanyak 23 mempunyai deskripsi data sebagai berikut: (a) jumlah skor total sebesar 1935; (b) nilai rata-rata hitung (mean) sebesar 84,13; (c) median sebesar 82,00; (d) modus sebesar 80; (e) standar deviasi sebesar 7,570; (f) nilai minimum sebesar 72; (g) nilai maximum sebesar 100 .

Kinerja karyawan yang dilaksanakan oleh PT Bank Syariah Mandiri Cabang Madiun, dikatakan rendah. Hal ini dapat dilihat dari hasil statistik deskriptif dengan jumlah (N) sebanyak 23 mempunyai deskripsi data sebagai berikut: (a) jumlah skor total sebesar 1978; (b) nilai rata-rata hitung (mean) sebesar 86.00; (c) median sebesar 85.00; (d) modus sebesar 85; (e) standar deviasi sebesar 6.928; (f) nilai minimum sebesar 77; (g) nilai maximum sebesar 100.

Pelatihan kerja pada "PT Bank Syariah Mandiri Cabang Madiun" Tahun 2012 mempunyai pengaruh terhadap kinerja karyawan. Terbukti dari sumbangan pelatihan terhadap kinerja dan hasil dari analisis regresi yang memuat uji korelasi, uji $\mathrm{F}$, dan uji $\mathrm{t}$ sebagai berikut:

\section{Analisis uji determinasi}

Nilai $R^{2}$ (R Square) yang digunakan untuk mengetahui seberapa besar prosentase sumbangan pelatihan kerja terhadap kinerja karyawan. Diketahui nilai $\mathrm{R}^{2}$ adalah 0,654. Jadi sumbangan pengaruh dari pelatihan kerja terhadap kinerja karyawan yaitu $65,4 \%$ sedangkan sisanya sebesar $34,6 \%$ dipengaruhi oleh faktor lain. 


\section{Hasil uji korelasi}

Nilai $r_{\text {hitung }}$ adalah 0,809 sedangkan $r_{\text {tabel }}$ 0,413 , dilain pihak besarnya $\mathrm{Sig}_{\text {hit }}$ adalah 0,000 sedangkan $\operatorname{Sig}_{\text {prob }}$ 0,05. Hal ini berarti bahwa nilai $r_{\text {hitung }} \geq r_{\text {tabel }}(0,809 \geq 0,413)$ atau $\operatorname{Sig}_{\text {hit }} \leq \operatorname{Sig}_{\text {prob }}(0,000 \leq 0,05)$, artinya pelatihan kerja mempunyai hubungan yang positif dengan kinerja karyawan pada PT Bank Syariah Mandiri Cabang Madiun tahun 2012.

\section{Hasil uji F}

Nilai $F_{\text {hitung }}$ adalah 39,678 sedangkan $F_{\text {tabel }}$ sebesar 4,325, dilain pihak besarnya $\mathrm{Sig}_{\text {hit }}$ adalah 0,000 sedangkan $\operatorname{Sig}_{\text {prob }}$ 0,05. Hal ini berarti bahwa nilai $\mathrm{F}_{\text {hitung }} \geq \mathrm{F}_{\text {tabel }}(39,678 \geq$ 4,325) atau $\operatorname{Sig}_{\text {hit }} \leq \operatorname{Sig}_{\text {prob }}(0,000 \leq 0,05)$, artinya pelatihan kerja mempunyai pengaruh terhadap kinerja karyawan pada PT Bank Syariah Mandiri Cabang Madiun tahun 2012.

\section{Hasil uji t}

Nilai $t_{\text {hitung }}$ adalah 6,299 sedangkan $t_{\text {tabel }}$ sebesar 1,721, dilain pihak nilai Sig $_{\text {hit }}$ adalah 0,000 sedangkan $\operatorname{Sig}_{\text {prob }}$ 0,05. Hal ini berarti bahwa nilai $\mathrm{t}_{\text {hitung }} \geq \mathrm{t}_{\text {tabel }}(6,299 \geq 1,721)$ atau $\operatorname{Sig}_{\text {hit }} \leq \operatorname{Sig}_{\text {prob }}(0,000 \leq 0,05)$, artinya pelatihan kerja mempunyai beda pengaruh terhadap kinerja karyawan pada PT Bank Syariah Mandiri Cabang Madiun tahun 2012.

\section{Saran}

\section{Bagi Karyawan}

Pelatihan kerja terbukti memberikan hubungan serta pengaruh terhadap kinerja karyawan, oleh karena itu karyawan hendaknya bersungguh-sungguh dalam mengikuti pelatihan serta menjadikan pelatihan sebagai cara atau upaya untuk meningkatkan kinerja. Dan juga hendaknya selalu mempertahankan bahkan meningkatkan kualitas kerjanya.

\section{Bagi Perusahaan}

Pelatihan hendaknya tetap terus diberikan dan berkesinambungan kepada setiap karyawan, bahkan sejak awal penempatan karyawan agar dalam menghadapi pekerjaannya karyawan dapat menyesuaikan diri dengan cara kerja yang berlaku di perusahaan. Selain itu juga untuk mempertahankan eksistensi perusahaan dalam menghadapi persaingan dunia usaha.

\section{Bagi Peneliti Mendatang}

Bagi peneliti yang selanjutnya, sebaiknya mengadakan pengembangan penelitian ini dengan menambah atau mencari variabel lain selain pelatihan kerja karena masih banyak faktor yang mempengaruhi kinerja karyawan.

\section{DAFTAR PUSTAKA}

A. A. Anwar Prabu Mangkunegara. 2005. Evaluasi Kinerja SDM. Bandung: Refika Aditama.

Duwi Priyatno. 2010. Teknik Mudah dan Cepat Melakukan Analisis Data Penelitian Dengan SPSS dan Tanya Jawab Ujian Pendadaran. Yogyakarta:Gava Media.

Edy Sutrisno. 2009. Manajemen Sumber Daya Manusia. Jakarta: Prenada Media Group.

Gabriel Amin Silalahi. 2003. Metodologi Penelitian dan Studi Kasus. Sidoarjo: Citra Media.

Husaini dan Purnomo.2006. Pengantar Statistika. Jakarta: PT Bumi Aksara

Husein Umar. 2011. Metode Penelitian Untuk Skripsi dan Tesis Bisnis. Jakarta: PT. Raja Grafindo Persada.

Iqbal Hasan. 2004. Analisis Data Penelitian Dengan Statistik. Jakarta:Bumi Aksara.

Juliansyah Noor. 2011.Metodologi Penelitian: Skripsi, Tesis, Disertasi, dan Karya Ilmiah.Jakarta:Prenada Media Group. 
Moehar Daniel. 2003. Metode Penelitian Sosial Ekonomi. Jakarta: PT. Bumi Aksara.

Moeheriono. 2010. Pengukuran Kinerja Berbasis Kompetensi. Bogor: Ghalia Indonesia

Nasution, S. 2004. Metodologi Research: Penelitian Ilmiah. Jakarta: PT. Bumi Aksara.

Oemar Hamalik.2007. Manajemen Pelatihan Ketenagakerjaan Pendekatan Terpadu:Pengembangan Sumber Daya Manusia, Jakarta: Bumi Aksara

Sedarmayanti. 2011. Membangun dan Mengembangkan Kepemimpinan Serta Meningkatkan Kinerja Untuk Meraih Keberhasilan. Bandung: Refika Aditama

Siswanto, B Sastrohadiwiryo. 2005. Manajemen Tenaga Kerja Indonesia Pendekatan Administrasi dan Operasional. Jakarta: PT. Bumi Aksara.

Sjafri Mangkuprawira. 2002. Manajemen Sumber Daya Manusia Strategik. Jakarta: Ghalia Indonesia

Sjafri Mangkuprawira.2009. Bisnis, Manajemen, dan Sumber Daya Manusia. IPB: Gramedia
Sugiyono. 2008. Statistika untuk Penelitian. Bandung: Alfabeta

Sugiyono. 2010. Metode Penelitian Pendidikan. Bandung: Alfabeta

Suharsimi Arikunto. 2010. Prosedur Penelitian Suatu Pendekatan Prektik. Jakarta: Rineka Cipta.

Sunarto dan Sahedhy, R Noor. 2003. Manajemen Sumber Daya Manusia. Yogyakarta: BPFE-UST Yogyakarta.

Suwatno dan Doni Priansa. 2011. Manajemen SDM Dalam Organisasi Publik dan Bisnis. Bandung: Alfabeta

Undang-Undang RI No.10 Tahun 1998 Tentang Perbankan

Usman Rianse dan Abdi. 2009. Metodologi Penelitian Sosial dan Ekonomi: Teori dan Aplikasi. Bandung: Alfabet.

Wibowo. 2007. Manajemen Kinerja. Jakarta: Raja Grafindo Persada

Wilson Bangun. 2012. Manajemen Sumber Daya Manusia. Jakarta: Erlangga 